ks. Marek Parchem

\title{
Gatunek i formy literackie w Księdze Daniela
}

\section{Nazewnictwo i klasyfikacja}

Jednym z zagadnień, które wzbudza wiele kontrowersji w interpretacji Księgi Daniela, jest problem określenia jej gatunku literackiego. Odnosi się to zarówno do „zdefiniowania” gatunku literackiego Księgi jako całości, jak również do właściwego ujęcia i wyodrębnienia różnorodnych form literackich w niej występujących. W starożytności Księga Daniela była generalnie uznawana za księge prorocką ${ }^{1}$. Józef Flawiusz nazywa Daniela „prorokiem”, ponieważ „on nie tylko przepowiadał proroczo przyszłe wydarzenia, jak to czynili również inni prorocy, ale nawet określał porę, w jakiej one nastąpią" (Ant. X. 11. 7). Wyraźne cytowanie Księgi jako pisma prorockiego pojawia się w 4QFlorilegium 2, 3 (= 4Q174): ,jak zostało napisane w Księdze Daniela, proroka...”. Godne uwagi jest również świadectwo Mt 24, 15: „gdy więc zobaczycie ohydę spustoszenia, o której mówił prorok Daniel, stojącą w miejscu świętym...”. Również we wczesnych źródłach rabinicznych Daniel jest zaliczany do grona proroków (np. Mechilta 1b; Pesiqta Rabbati 14, 61; Pesiqta de Rab Kahana 4, 36b; Seder 'Olam 20)². Tym niemniej w Biblii Hebrajskiej Księga Daniela znalazła się wśród Pism, a nie Proroków. Z drugiej strony już w Talmudzie babilońskim pojawia się pogląd, że Daniel nie był prorokiem (Sanhedrin 94a). Późniejsza tradycja żydowska interpretuje ten fakt tym, że Daniel otrzymywał objawienie nie bezpośrednio, jak zwykle otrzymywali je prorocy, ale w snach ${ }^{3}$. Jednakże ani traktowanie Daniela jako proroka przez starożytnych, ani umiejscowienie Księgi w kanonie nie jest czynnikiem ułatwiającym określenie gatunku literackiego Księgi.

Kwestia określenia gatunku literackiego Księgi Daniela wysunęła się na czoło wraz z pojawieniem się krytycznego i naukowego podejścia do badań nad Księgą i była ściśle związana z zagadnieniem jej autentyczności.

\footnotetext{
${ }^{1}$ Zob. K. Koch, Is Daniel also among the Prophets?, Int 39 (1985), 117-130.

${ }^{2}$ Zob. B. Fischer, Daniel und Seine Drei Gefährten in Talmud und Midrasch, Bern 1906, 98-99.

${ }^{3}$ Zob. M. Maimonides, The Guide of the Perplexed, trans. S. Pines, Chicago 1963, 400.
} 
Już w początkach XVII wieku Uriel da Costa, porównując Księgę Daniela z innymi pismami apokryficznymi, zwłaszcza z 4 Księgą Ezdrasza, stwierdził późną datę kompozycji dzieła. Wiek później A. Collins włączył Dn i 4 Ezd do grupy pism razem z innymi apokryfami i jednocześnie wyodrębnił różnice stylistyczne istniejące pomiędzy Dn a księgami prorockimi. Nowe światło na literacki kontekst Księgi Daniela rzuciły odkrywane i publikowane, zwłaszcza w XIX w. oraz początkowych latach XX w., liczne pisma apokryficzne, zwłaszcza o charakterze apokaliptycznym. Studia porównawcze takich pism jak: Księga Henocha etiopska, 4 Księga Ezdrasza, Apokalipsa Barucha syryjska (2 Bar), Testament Mojżesza, Testament Abrahama, Apokalipsa Barucha grecka (3 Bar), Apokalipsa Abrahama i inne wykazały, że istnieje wiele literackich podobieństw pomiędzy pismami uważanymi za apokaliptyczne. Dało to początek badaniom gatunku literackiego Księgi Daniela w kontekście innych pism apokaliptycznych ${ }^{4}$.

\section{Księga Daniela jako „całość”}

Generalnie, Księgę Daniela w dzisiejszej jej formie określa się mianem „apokalipsy"5. Wciąż jednak wśród uczonych trwają dyskusje odnośnie do precyzyjnego zdefiniowania terminu ,apokalipsa”, lecz bez rezultatu6. Różnica zdań dotyczy przede wszystkim liczby i ważności elementów, które są uważane za charakterystyczne dla tego typu literatury, oraz zależy od tego, które z tych elementów uważa się za dominujące ${ }^{7}$. Ponadto wydaje się również istotnym przy określaniu literackiego statusu pism apokaliptycznych uwzględnienie ich Sitz im Leben ${ }^{8}$. Ze względu na trudności związane z definiowaniem terminów „apokalipsa” i ,apokaliptyka” istnieje obecnie wśród uczonych tendencja, aby na polu badań zajmujących się tym zagadnieniem raczej nie dążyć do ścisłego definiowania, ile pozostać przy określaniu zarówno społeczności,

${ }^{4}$ Zob. szerzej: J. J. Collins, Daniel. A Commentary on the Book of Daniel, Minneapolis 1993, 52-54 (Hermeneia).

5 Zob. K. Koch, The Rediscovery of Apocalyptic, trans. M. Kohl, London 1972, 23; J. Lebram, Daniel / Danielbuch und Zusätze, [w:] TRE 8, 328; J. J. Collins, Daniel with an Introduction to Apocalyptic Literature (FOTL 20), Grand Rapids 1984, 33; E. SCHÜRER, The History of the Jewish People in the Age of Jesus Christ (175 B.C. - A.D. 135), eds. G. Vermes, F. Millar, M. Goodman, t. 3.1, Edinburgh 1995, 245-250.

${ }^{6} \mathrm{Na}$ temat różnych propozycji zdefiniowania terminów ,apokalipsa” i ,apokaliptyka” oraz wyodrębnienia poszczególnych elementów w ramach omawianego zagadnienia zob. E. P. SANDERs, The Genre of Palestinian Jewish Apocalypses, [w:] Apocalypticism in the Mediterranean World and the Near East. Proceedings of the International Colloquium on Apocalypticism, Uppsala, August 12-17, 1979, ed. D. Hellholm, Tübingen 1983, 447-459; L. Hartman, Survey of the Problem of Apocalyptic Genre, [w:] Apocalypticism, ed. D. Hellholm, 329-343.

${ }^{7}$ Zob. J. Homerski, Dn 1-6 - pareneza czy eschatologia?, RTK 29 (1982), 24.

${ }^{8}$ Zob. E. P. SANDERs, The Genre, [w:] Apocalypticism, ed. D. Hellholm, 448. 
w której powstawała, jak i prądów religijnych, które znalazły swoisty sposób ekspresji swej doktryny w specyficznych formach literackich ${ }^{9}$.

J. J. Collins jest zdania, że Księga Daniela traktowana jako całość jest apokalipsą, jeśli przyjmie się, że termin „apokalipsa”"10 jest określeniem gatunku literackiego, który opisuje objawienie za pomocą narracji. To objawienie jest przekazywane człowiekowi najczęściej przez istotę pozaziemską: zawiera odsłonięcie rzeczywistości transcendentnej, w której występuje zarówno doczesne (czasowe), jak i eschatologiczne (wieczne) zbawienie oraz ziemski i nadprzyrodzony świat. Biorąc pod uwagę elementy, które charakteryzują gatunek literacki nazywany „apokalipsą”, między innymi istnienie vaticinia ex eventu dotyczących historii i jej periodyzacji (np. w Dn 2 i 7) oraz eschatologii mającej kosmiczny charakter i skupiającej się wokół wymiaru politycznego (podporządkowanie ziemskich władców królewskiemu panowaniu Boga), zalicza on Księgę Daniela do grupy tzw. „apokalips historycznych". Nie zawiera ona podróży do innego świata, podobnie jak Księga Snów, Apokalipsa Tygodni, Księga Jubileuszy, 4 Księga Ezdrasza i 2 Księga Barucha ${ }^{11}$.

K. Koch ${ }^{12}$ proponuje, aby apokaliptykę (apokalipsę) traktować jako zbiór lub kompozycję gatunków literackich, na którą składają się różne komponenty lub podgatunki. Biorąc pod uwagę sześć dzieł, które określa jako apokalipsy: Księgę Daniela, 1 Księgę Henocha, 4 Księgę Ezdrasza, 2 Księgę Barucha, Apokalipsę Abrahama i Apokalipsę św. Jana, wyróżnia sześć cech charakterystycznych wyodrębnionych na drodze analizy krytyki form ${ }^{13}$ oraz osiem typowych idei ${ }^{14}$, które stanowią podstawowe elementy

${ }^{9}$ Zasadą „contra definitionem, pro descriptione” kierowali się uczestnicy międzynarodowego kolokwium na temat zjawiska apokaliptyki, które odbyło się 12-17 sierpnia 1979 roku w Upsali. Zob. D. Hellholm, Introduction, [w:] Apocalypticism, ed. D. Hellholm, 2.

${ }^{10}$ Zob. J. J. Collins, Apocalypse: The Morphology of a Genre, "Semeia" 14 (1979), 9.

${ }^{11}$ Zob. J. J. Collins, Apocalypse: The Morphology of a Genre, 11; TENŻE, Daniel with an Introduction, 12; TENŻE, The Apocalyptic Imagination. An Introduction to the Jewish Matrix of Christianity, New York 1989, 5-6.

12 Zob. K. Косн, The Rediscovery of Apocalyptic, 18-35.

${ }^{13}$ Są to: 1 . Wizje, które często zawierają dialog między człowiekiem a istotą nadziemską; 2. Reakcja człowieka na wizję, a więc duchowy wstrząs; 3 . Mowy napominające skierowane do uczniów; 4. Pseudonimia; 5. Obrazy czerpane z mitologii bogate w symbolikę; 6. Bardzo długi okres literackiego rozwoju, którego rezultatem jest tekst danego dzieła w dzisiejszej jego formie; zob. szerzej: The Rediscovery of Apocalyptic, 24-28.

${ }^{14}$ Są to: 1 . Oczekiwanie na zmianę i odnowienie ziemskiej rzeczywistości w przyszłości; 2 . Nadejście kosmicznej katastrofy, która stanowić będzie znak eschatologicznego końca; 3. Podział czasu i dziejów na poszczególne etapy, które są zdeterminowane od stworzenia izinterpretowane przez proroków; 4. Wiara w istnienie i działanie aniołów i demonów oraz w istnienie historii ziemskiej paralelnej do niebiańskiej w przyszłym, eschatologicznym czasie; 5. Zbawienie nawiązujące do rzeczywistości rajskiej; 6. Ustanowienie Królestwa Bożego na ziemi; 7. Pośrednik (Mesjasz, Syn Człowieczy, Wybraniec) 
tych kompozycji. Uwzględniając spostrzeżenia K. Kocha można określić literaturę apokaliptyczną, w tym również Księgę Daniela, jako pewnego rodzaju zbiór gatunków literackich, który swymi korzeniami sięga tradycji prorockich i mądrościowych ${ }^{15}$.

Wiele dyskusji wzbudza fakt istnienia w Księdze Daniela części narracyjnej (opowiadania w Dn 1-6) oraz apokaliptycznych wizji (Dn 7-12). Można przypuszczać, że opowiadania w Dn 1-6 zostały połączone z pozostałą częścią Księgi, aby stanowić pewnego rodzaju fikcyjne tło dla wizji w Dn 7-12. Jest prawdą, że element apokaliptyczny w ścisłym sensie jest ograniczony do późniejszych rozdziałów Księgi Daniela. Ale równocześnie w opowiadaniach Dn 1-6 znajdują się pewne elementy apokaliptyki, które pozwalają na stwierdzenie, że wizje w Dn 7-12 wydają się być ich kontynuacją ${ }^{16}$. Dn 2 zawiera senną wizję i alegoryczną interpretację z eschatologiczną konkluzją w ww. 44-45. W Dn 4 znajduje się interpretacja tajemniczego snu, a w Dn 5 interpretacja napisu na ścianie. Każdy z tych rozdziałów zawiera przepowiednię o przemianie politycznego porządku, ale tylko rozdz. 2 może być traktowany jako ściśle eschatologiczny, ponieważ mówi o definitywnej przemianie świata, która dokona się przez ustanowienie Królestwa Bożego. P. R. Davies sugeruje, że opowiadania w Dn 1-6 mają charakter eschatologiczny nie tyle co do szaty literackiej, ile co do treści. W ten sposób Księga Daniela stanowi przemyślaną kompozycję, w której opowiadania (1-6) posłużyły jako wprowadzenie do części zawierającej wizje (7-12) ${ }^{17}$.

Na ogół przyjmuje się, że opowiadania w Dn 1-6, pierwotnie istniejące samodzielnie i niezależnie od siebie ${ }^{18}$, pochodzą z czasów przedmachabejskich i zawierają materiał sięgający korzeniami wspólnej dla starożytnej literatury Bliskiego Wschodu tradycji poezji epickiej, której początek stanowił przekaz ustny ${ }^{19}$. Tego typu literatura, często mająca charakter propagandy

posiadający królewskie prerogatywy jako przedstawiciel Boga jest gwarantem ostatecznego zbawienia; 8. Chwalebna przemiana struktur społecznych; zob. The Rediscovery of Apocalyptic, 28-33.

${ }^{15}$ Zob. J. G. Gammie, The Classification, Stages of Growth, and Changing Intentions in the Book of Daniel, JBL 95 (1976), 192-193.

${ }^{16}$ Zob. P. R. DAVIES, Eschatology in the Book of Daniel, JSOT 17 (1980), 39.

${ }^{17}$ Zob. tamże, 47.

${ }^{18}$ Znaczne różnice pomiędzy TM a przekładem greckim (LXX) sugerują, że opowiadania w D 1-6 istniały pierwotnie niezależnie od siebie, a najwcześniejszą kolekcją był Dn 3, 31 - 6, 29; zob. K. Koch, Das Buch Daniel, Darmstadt 1980, 75 (EF 144); E. HAAG, Die Errettung Daniels aus der Löwengrube. Untersuchungen zum Ursprung der biblischen Danieltradition, Stuttgart 1983, 12 (SBS 110); J. J. Collins, Daniel, 37; por. L. M. Wills, The Jew in the Court of the Foreign King. Ancient Jewish Court Legends, Minneapolis 1990, 144-152 (HDR 26); R. AlbERTZ, Der Gott des Daniel. Untersuchungen zu Daniel 4-6 in der Septuagintafassung sowie zu Komposition und Theologie des aramäischen Danielbuches, Stuttgart 1988, 157-170 (SBS 131); T. J. MEADowCroft, Aramaic Daniel and Greek Daniel: A Literary Comparison, Sheffield 1995 (JSOTSup 198). 
politycznej, rozwijająca się w Babilonii, Persji i imperium Seleucydów²0, była także rozpowszechniona wśród żydowskich wygnańców mieszkających w diasporze ${ }^{21}$. Brak jakichkolwiek aluzji do Machabeuszy pozwala przypuszczać, że opowiadania w Dn 1-6 tworzyły samodzielną aramejską kompozycję w czasach przed Antiochem Epifanesem, do której na początku czasów machabejskich dołączono wizję Dn 7 przedstawiającą upadek imperium Seleucydów, a następnie wizje w Dn 8-12 w języku hebrajskim ${ }^{22}$.

Na ogół przyjmuje się, że wizje w Dn 7-12 powstały w okresie machabejskim (167-164 przed Chr.), chociaż niektórzy sugerują wcześniejsze powstanie Dn $7^{23}$. Jest to również okres, w którym nastąpiła ostateczna redakcja całej Księgi polegająca na połączeniu opowiadań (1-6), aramejskiej wizji (7) oraz hebrajskich wizji (8-12) w jedną całość.

\section{Opowiadania: Dn 1-6}

Pomocą w określeniu gatunku literackiego opowiadań zawartych w Dn 1-6 jest obecność w nich nieścisłości dotyczących faktów historycznych. To

${ }^{19}$ Zob. L. M. Wills, The Jew in the Court of the Foreign King, 83-85; R. G. KRATZ, Translatio imperii. Untersuchungen zu den aramäischen Danielerzählungen und ihrem theologiegeschichtlichen Umfeld, Neukirchen-Vluyn 1991, 134-148 (WMANT 63). Analizę lingwistyczną Księgi Daniela, potwierdzającą jej orientację babilońską przeprowadza m.in. F. Polak, The Daniel Tales in their Aramaic Literary Milieu, [w:] The Book of Daniel in the Light of New Findings, ed. A. S. van der Woude, Leuven 1993, 254-260 (BETL 106); P. W. Coxon, The Syntax of the Aramaic of Daniel: A Dialectal Study, HUCA 48 (1977), 119-122; por. W. BAUMGARTNER, Das Aramäische im Buche Daniel, ZAW 45 (1927), 81-133.

${ }^{20}$ Przykładem może być tzw. Modlitwa Nabonida, fragmentarycznie zachowany dokument odnaleziony w Qumran, który nawiązuje do Księgi Daniela i stanowi świadectwo istniejącej tradycji propagandowej, która służyła usankcjonowaniu roszczeń do prawowitej władzy, a przez redaktora żydowskiego zaadoptowana jako wyraz uznania w Bogu Najwyższego Władcy przez pogańskiego króla. Tekst opublikował J. J. Collins, 242. 4Q Prayer of Nabonidus, [w:] Qumran Cave 4. XVII. Parabiblical Texts, Part 3, eds. G. J. Brooke, et al., Oxford 1996, 83-93 (DJD 22). Na temat związków z Księgą Daniela, które w dużej mierze zależą od rekonstrukcji tekstu zob. J. J. Coluns, New Light on the Book of Daniel from the Dead Sea Scrolls, [w:] Perspectives in the Study of the Old Testament and Early Judaism. A Symposium in Honour of A. S. van der Woude on the Occasion of His $70^{\text {th }}$ Birthday, eds. F. García Martínez, E. Noort, Leiden 1998, 181-187 (VTSup 73). Na temat odmiennych rekonstrukcji zob. F. M. Cross, Fragments of the Prayer of Nabonidus, IEJ 34 (1984), 260-264; F. GarCíA MARTíneZ, Qumran and Apocalyptic. Studies on the Aramaic Texts from Qumran, Leiden 1992, 116136 (STDJ 9); E. PuECH, La prière de Nabonide (4Q242), [w:] Targumic and Cognate Studies: Essays in Honour of M. McNamara, eds. K. J. Cathcart, M. Maher, Sheffield 1996, 208-227.

${ }^{21}$ Zob. W. von SodEN, Eine babylonische Volksüberlieferung von Nabonid in den Danielerzählungen, ZAW 53 (1935), 81-89.

22 Zob. J. J. Collins, Daniel, 36.

${ }^{23}$ Powstanie Dn 7 w epoce przedmachabejskiej w ogólnej hipotezie powstania Dn 1-7 oraz istnienia aramejskiej części Księgi jako całościowej kompozycji, przyjmują z różnymi modyfikacjami m.in. R. AlberTz, Der Gott des Daniel, 171-184; R. G. KRATZ, Translatio imperii, 
dowodzi, że opowiadania nie są pismami historycznymi, ile raczej historiograficznymi. Należy więc zwrócić uwagę na cechy charakterystyczne opowiadań, między innymi na ich stereotypową konstrukcję, która ma swoje paralele w literaturze Bliskiego Wschodu, oraz częste występowanie cudownych zdarzeń, takich jak napis na ścianie (Dn 5) czy transformacja Nabuchodonozora w bestię (Dn 4). Te elementy dowodzą, że intencją i celem opowiadań nie było przekazywanie faktów historycznych, lecz wprowadzenie atmosfery grozy i cudowności. Ten ostatni aspekt jest podkreślany przez liczne dokso$\operatorname{logie}^{24}$. Istnieje wiele propozycji na określenie opowiadań w Dn 1-6, a są one wynikiem zastosowania różnych metod badawczych ${ }^{25}$.

Jednym z określeń opowiadań w Dn 1-6 jest „midrasz”. Określenie to wśród wielu uczonych stało się terminem technicznym na oznaczenie formy literackiej, w której główną cechą, a jednocześnie celem jest interpretacja tekstu biblijnego. Dla midraszu punktem wyjścia jest zawsze tekst biblijny, który jest wyjaśniany i aktualizowany przez ludzi żyjących w późniejszych czasach. Przybierał on różne formy i dlatego mówi się o midraszu homiletycznym, egzegetycznym i narracyjnym ${ }^{26}$.

Mając na uwadze paralele istniejące między opowiadaniami w Dn 1-6 a starszymi tekstami biblijnymi, C. Gaide ${ }^{27}$ oraz M. Delcor $^{28}$ traktują Dn 1-6 jako midrasz do opowiadań o Józefie z Księgi Rodzaju. L. F. Hartman i A. A. DiLella ${ }^{29}$ proponują obok nazwy midrasz określenie „opowiadanie pouczające", a F. Nötscher chcąc podkreślić liczne wzmianki natury historycznej nazywa pierwszą część Księgi Daniela „midraszem z historycznym tłem (podłożem)" "30. A. Lacocque sugeruje, aby opowiadania Dn 1-6 nazwać zbiorem haggad. W jego ujęciu haggada obejmuje wszystko to, co nie dotyczy kodyfikacji Prawa, czyli halachy, a więc legendę, opowiadanie,

6-42; H. L. GinsBerg, Studies in Daniel, New York 1948, 11-23 (Jewish Theological Seminary of America, 14); TENŻE, The Composition of the Book of Daniel, VT 4 (1954), 264 i 268; L. F. HARTman, A. A. DiLella, The Book of Daniel. A New Translation with Notes and Commentary, New York 1978, 13 (AB 23). L. Dequeker, The 'Saints of the Most High' in Qumran and Daniel, OTS 18 (1973), 111-133, uważa, że pierwotny materiał Dn 7 został zaktualizowany przez redaktora z czasów machabejskich.

${ }^{24}$ Zob. J. J. Collins, Daniel, Book of, [w:] ABD 2, 31.

${ }^{25}$ K. Koch, Das Buch Daniel, 88-91 wyróżnia pięć odrębnych form literackich w odniesieniu do opowiadań Dn 1-6: baśń, legenda, opowiadanie dworskie, romans i midrasz.

${ }^{26}$ Zob. A. G. Wright, The Literary Genre Midrash (I), CBQ 28 (1966), 120-128.

${ }^{27}$ Zob. C. Gaide, Le Livre de Daniel, Paris 1969, 19-20.

${ }^{28}$ Zob. M. Delcor, Le Livre de Daniel, Paris 1971, 23 (SB 4).

${ }^{29}$ Zob. L. F. Hartman, A. A. DiLella, The Book of Daniel, 54-55. Opowiadania Dn 1-6 nazywają oni również religijnymi romansami lub popularnymi opowiadaniami o sukcesie czy o mądrym dworzaninie i zaliczają je do „specyficznegu typu midraszu”, podobnie jak opowiadania o Józefie, Esterze, Tobiaszu i Judycie, apokryficznej 3 Księgi Ezdrasza i Historii Achikara.

${ }^{30}$ F. NöTscher, Das Buch Daniel, Würzburg 1958, 597 (Echter Bibel, 3). 
homilię, wyjaśnienie, przypowieści i historiografię. Jego zdaniem haggada odpowiada określeniu midrasz, przy czym w przeciwieństwie do midraszu nie musi opierać się o tekst biblijny ${ }^{31}$.

Często określenie midrasz odnosi się do Księgi Daniela, ponieważ znajduje się w niej wiele aluzji do wcześniejszych tekstów biblijnych, podobnie jak w innych apokalipsach. Można ewentualnie przyjąć, że teksty apokaliptyczne i midrasz, chociaż stanowią różne formy literackie, niekiedy występują razem jako zespół literackich form, wtedy mianowicie, gdy apokalipsa zajmuje się i bada teksty wcześniejsze lub odwrotnie, gdy midrasz interpretuje tekst w sposób charakterystyczny dla apokalipsy. Wydaje się jednak, że to określenie w odniesieniu do Dn 1-6 jest niewłaściwe, gdyż występowanie aluzji czy motywów zaczerpniętych z wcześniejszych tradycji biblijnych w określonym tekście nie daje podstaw do nazywania go midraszem ${ }^{32}$.

E. W. Heaton nazywa opowiadania w Dn 1-6, ,romansami” i rozumie przez to określenie popularne opowiadania fikcyjne ${ }^{33}$. W kontekście literatury hellenistycznej bardzo często istotnym elementem romansu jest intryga o charakterze erotycznym ${ }^{34}$. Taka intryga, chociaż nie stanowiąca głównego motywu w utworze, występuje w opowiadaniach o Józefie i Esterze oraz jest widoczna w opowiadaniu o Zuzannie, ale jest całkowicie obca opowiadaniom w Dn 1-6. Reprezentatywnym przykładem żydowskiego opowiadania romantycznego jest apokryficzny utwór Józef i Asenat ${ }^{35}$. Niekiedy w nawiązaniu do hellenistycznych romansów nazywa się tę kategorię literatury w znaczeniu szerszym „nowelą” lub „krótką opowieścią”36, ale takie określenia wydają się zbyt ogólne i nie precyzują specyficznych cech opowiadań zawartych w Dn 1-6.

Przez zwolenników krytyki form, zwłaszcza uczonych niemieckich, opowiadania w Dn 1-6 są określane terminem „baśń”, ale tylko w odniesieniu do pewnego stadium rozwoju tradycji ${ }^{37}$. W ich rozumieniu baśń jest tradycyjnym

${ }^{31}$ Zob. A. Lacocoue, The Book of Daniel, trans. D. Pellauer, Atlanta 1979, 8.

${ }^{32}$ Jako midrasz w znaczeniu formy literackiej może być traktowany jedynie tekst w Dn 9, 20-27, który stanowi midrasz egzegetyczny do Jr 25, 11-12; 29, 10; zob. szerzej A. G. WRIGHT, The Literary Genre Midrasz (II), 453; J. J. Collins, Daniel, 39-40.

${ }^{33}$ Zob. E. W. HeAton, The Book of Daniel: Introduction and Commentary, London 1956, 38 (TBC). Podobnie J. G. Gammie, The Classification, 193; L. F. Hartman, A. A. Dilella, The Book of Daniel, mówią o romansie religijnym.

${ }^{34}$ Zob. M. Hengel, Judaism and Hellenism: Studies in their Encounter in Palestine during the Early Hellenistic Period, t. 1, trans. J. Bowden, Philadelphia 1974, 110.

${ }^{35}$ Zob. J. J. Collins, Daniel, 42.

${ }^{36}$ Zob. D. N. Fewell, Circle of Sovereignty: A Story of Stories in Daniel 1-6, Sheffield 1988, 10 (JSOTSup 72).

${ }^{37}$ Zob. H. GunKEL, Das Märchen im Alten Testament, Tübingen 1921, 106 i 142; W. BAUMGARTNER, Ein Vierteljahrhundert Danielforschung, ThR 11 (1939), 133-135; H. P. MüLLER, Märchen, Legende und Enderwartung: Zum Verständnis des Buches Daniel, VT 26 (1976), 338-50. 
opowiadaniem narracyjnym, którego akcja rozgrywa się w tajemniczym świecie fantazji i zmierza do sprowokowania sympatii czytelnika dla głównego bohatera. Kluczowym elementem baśni jest świat fantazji, dlatego trudno o argumenty, które by potwierdziły przynależność opowiadań w Dn 1-6 do tego typu narracji, zważywszy na to, że akcja opowiadań w Dn rozgrywa się w świecie realnym. Można się zgodzić z twierdzeniem, że w opowiadaniach w Dn 1-6 występują motywy fantastyczne: przemiana Nabuchodonozora w bestię (Dn 4) i tajemniczy napis na ścianie (Dn 5), ale to jeszcze nie jest powodem, aby cała kompozycję traktować jako baśń. H. P. Müller sugeruje, że pierwotnie te dwa opowiadania mogły mieć charakter baśni, tym bardziej że został udokumentowany długi proces ich powstawania, zwłaszcza Dn 4, ale w dzisiejszej formie tych opowiadań trudno zrekonstruować ich pierwotną formę ${ }^{38}$.

Dużym uznaniem wśród wielu uczonych, którzy do badań nad formą literacką włączyli również analizę socjologiczną, cieszy się określenie opowiadań w Dn 1-6 jako „opowiadania dworskie”39. Podstawową i kluczową cechą opowiadań w Dn 1-6 jest umiejscowienie ich akcji na królewskim dworze. Jednak wśród typu literatury, który reprezentują opowiadania dworskie, można wyodrębnić wiele podrzędnych form o charakterze ludowym, między innymi legendy, sagi i nowele, których Sitz im Leben nie jest królewski dwór. Z tego względu przy określaniu formy literackiej danej narracji, którą charakteryzuje się jako opowiadanie dworskie, w analizie krytyki form należy uwzględnić raczej ich Sitz im Leben i fabułę niż formę narracyjną czy intencję ${ }^{40}$. Opowiadania o Danielu i jego towarzyszach, którzy są ukazani w opowiadaniach jako mędrcy na królewskim dworze, stanowią typ literatury znany na całym Bliskim Wschodzie. Opowiadania o dworzanach lub doradcach królewskich oraz ich przygodach, a zwłaszcza o osiąganych przez nich sukcesach na dworze, o intrygach i niebezpieczeństwach, jakich doświadczali, były szeroko rozpowszechnione w literaturze Mezopotamii, Persji, Egiptu i Grecji ${ }^{41}$. Również w literaturze biblijnej można odnaleźć liczne przykłady opowiadań, których Sitz im Leben jest królewski dwór ${ }^{42}$.

${ }^{38}$ Zob. krytykę tego stanowiska J. J. Collins, Daniel with an Introduction, 41; TENŻE, Daniel, 42.

${ }^{39}$ Zob. W. L. Humphreys, A Life-Style for Diaspora: A Study of the Tales of Esther and Daniel, JBL 92 (1973), 211-223; J. J. Collins, The Court-Tales in Daniel and the Development of Apocalyptic, JBL 94 (1975), 218-234; M. HENGEL, Judaism and Hellenism, t. 1, 30-31; szerzej na temat historii i metod analizy socjologicznej w badaniu Księgi Daniela zob. P. R. DAvies, Reading Daniel Sociologically, [w:] The Book of Daniel, ed. A. S. van der Woude, 345-361.

${ }^{40}$ Zob. J. J. Collins, Daniel with an Introduction, 42.

${ }^{41}$ Zob. L. M. WiLls, The Jew in the Court of the Foreign King, 39-74. Do najbardziej znanych należą: Historia Achikara umiejscowiona na asyryjskim dworze, ANET 427-430; w literaturze perskiej opowiadanie o Zaratustrze na dworze króla Hystaspesa, Denkard 5 i 7; w literaturze egipskiej Historia Sinuhe, ANET 18-22; Podróż Wenamona do Fenicji, ANET 25-29; Skargi 
Kontekst opowiadań dworskich występujących w literaturze Bliskiego Wschodu jest bardzo ważny dla badań Dn 1-6 z dwóch względów: po pierwsze, pozwala dostrzec pewien stereotypowy model tych opowiadań z fikcyjną raczej niż historyczną fabułą; po drugie, powszechność występowania jak również stereotypowy model rzuca pewne światło na ich funkcję. L. M. Wills sugeruje, że opowiadania o dworskich doradcach dających rady mądrości, ukazujące władzę należącą do określonej grupy etnicznej, chcą podkreślić wyższość mądrości nawet wtedy, gdy jest ona wypowiadana przez ludzi o niższym statusie społecznym $^{43}$. Ten aspekt jest szczególnie obecny w opowiadaniach o Danielu i Esterze. Dla Żydów będących w niewoli był to sposób na zachowanie swej narodowej dumy, gdy mimo utraty niezależności politycznej ktoś, kto należał do ich narodu, uzyskiwał wysoką pozycję na dworze królewskim państwa, które tę niezależność i wolność polityczną im zabrało.

Opowiadania w Dn 1-6 w paralelizmie z innymi, zwłaszcza z opowiadaniami o Józefie i Esterze oraz z Historii Achikara, posiadają trzy wspólne motywy ${ }^{44}$ :

1. Uwydatniają mądrość lub zdolności i kompetencje dworzanina. Często kryzys, który prowadzi do przesłania mającego specyficzną naturę lub do akcji któregoś z dworzan, nabiera drugoplanowego znaczenia.

2. W sposób dramatyczny przedstawiają niebezpieczeństwo lub poniżenie, które grozi głównej postaci, oraz późniejsze jej ocalenie. Mędrzec lub dworzanin z różnych przyczyn jest prześladowany lub więziony, ale po ocaleniu cieszy się jeszcze większymi względami niż dawniej. Ta sytuacja ma służyć podkreśleniu roli, jaką spełnia mądrość lub zręczność dworzanina.

3. Mogą służyć jako forma specjalnego przesłania, które przekazuje dworzanin. To przesłanie może mieć formę mowy mądrościowej lub interpretacji snu.

Analizując opowiadania dworskie w Dn 2-6, W. L. Humphreys ${ }^{45}$ zaproponował ich podział i rozróżnienie pomiędzy „opowiadaniami o dworskim konflikcie”, do których zalicza Dn 3 i 6 oraz „opowiadaniami o dworskim współzawodnictwie", do których zalicza Dn 2, 4 i 5. Chociaż z nielicznymi zmianami, to rozróżnienie zostało zaakceptowane przez wielu uczonych ${ }^{46}$.

biednego wieśniaka, ANET 407-410; Pouczenia Onchszeszonkiego; w literaturze greckiej, szczególnie w Historiae Herodota, znane są opowiadania o Solonie na dworze króla Krezusa (I, 29-33), o Krezusie na dworze Cyrusa (I, 87-90) i Kambyzesa (III, 35-36).

${ }^{42}$ M.in. Mojżesz na dworze faraona (Wj 5-10); Natan na dworze króla Dawida (2 Sam 12, 1-14); kobieta z Tekoa przed Dawidem (2 Sam 14, 1-17); słudzy króla syryjskiego przed Achabem (1 Krl 20, 39-43); Józef na dworze faraona (Rdz 41); królowa Estera i Mardocheusz na dworze perskim.

${ }^{43}$ Zob. L. M. WiLls, The Jew in the Court of the Foreign King, 68-69.

${ }^{44}$ Zob. J. J. Collins, The Court-Tales, 219.

${ }^{45}$ Zob. W. L. Humphreys, A Life-Style for Diaspora, 217-220. 
Opowiadania dworskie o konflikcie w Dn 3 i 6 posiadają wiele podobieństw do opowiadań z historii o Józefie, Esterze, Achikarze, deuterokanonicznych opowiadań o Belu i wężu, jak również do historii Krezusa na dworze Kambyzesa według Herodota. W narracji każdego z tych opowiadań można dostrzec kilka podstawowych etapów:

1. Bohater (bohaterowie) cieszy się powszechnym uznaniem i żyje w dobrobycie ${ }^{47}$

2. Bohaterowi grozi niebezpieczeństwo, zwykle z powodu spisku ${ }^{48}$

3. Bohater jest skazany na śmierć lub karę więzienia ${ }^{49}$

4. Bohater zostaje ocalony, jego mądrość jest powszechnie uznana a sam otrzymuje awans na wyższe stanowisko ${ }^{50}$

Niekiedy opowiadania Dn 3 i 6 nazywa się „opowiadaniami o męczeństwie" 51 . Rzeczywiście bardzo ważnym elementem tych opowiadań jest prześladowanie trzech przyjaciół (Dn 3) i Daniela (Dn 6), ale jak to zauważył M. A. Beek ${ }^{52}$ opowiadanie, w którym główny bohater nie ginie, a wręcz

${ }^{46}$ J. J. Collins, The Court-Tales, 218-234, nazywa opowiadania dworskie o konflikcie ,opowiadaniami o uwolnieniu”, natomiast dla opowiadań o dworskim współzawodnictwie proponuje nazwę „opowiadania, które podkreślają zawarte w nich przesłanie”; TENŻE, The Apocalyptic Vision of the Book of Daniel, Missoula 1977, $27-59$ (HSM 16); zob. TENŻE, Daniel, 45-47. P. R. DAVIES, Daniel, Sheffield 1998, 50-52 (Old Testament Guides), proponuje dla opowiadań o konflikcie nazwę „opowiadania o uwolnieniu”, a dla opowiadań o współzawodnictwie „opowiadania interpretacyjne"; zob. też L. M. WiLls, The Jew in the Court of the Foreign King, 3nn.

${ }^{47}$ Dn 3, 12: towarzysze Daniela są przełożonymi prowincji; Dn 6, 1-4: Daniel jest jednym z trzech ministrów państwa; Rdz 39, 1-6: Józef jest zwierzchnikiem domu Potifara; Est 2, 17 19: Ester jest królową, Mardocheusz jest dozorcą na dworze; Achikar $(1,1)$ jest sekretarzem króla; Krezus jest doradcą króla.

${ }^{48}$ Dn 3, 8-18: trzej przyjaciele są oskarżeni; Dn 6, 5-14: satrapowie knują intrygę przeciwko Danielowi; Rdz 39, 13-18: Józef jest fałszywie oskarżony przez żonę Potifara; Est 3, 6: Haman knuje spisek, aby zgładzić Mardocheusza i wszystkich Żydów; Achikar (3, 7): Nadan knuje spisek przeciwko głównemu bohaterowi; Krezusowi grozi niebezpieczeństwo z powodu nagany Kambyzesa.

${ }^{49}$ Dn 3, 19-23: trzej przyjaciele są wrzuceni do rozpalonego pieca; Dn 6, 17: Daniel zostaje wtrącony do jaskini lwów; Rdz 39, 20: Józef zostaje uwięziony; Est 3, 13: zostaje wydany dekret o prześladowaniu Żydów; Achikar i Krezus zostają skazani na śmierć.

${ }^{50}$ Dn 3, 24-27: trzej przyjaciele zostają cudownie ocaleni, 3, 29-30: król obdarza zaszczytami trzech przyjaciół i uwielbia Boga; Dn 6, 21-24: Daniel zostaje cudownie ocalony, 6, 25-28: król obdarza zaszczytami Daniela i wielbi Boga; Rdz 41, 14: Józef jest wezwany, aby wyjaśnił sen, Rdz 41, 39-45: Józef ogłoszony wicekrólem; Est 8, 8: Żydzi zostają ocaleni na prośbę Estery, 8, 2: Mardocheusz jest mianowany przełożonym w domu Hamana; Achikar $(4,12)$ zostaje ocalony, w 5, 7 jest wezwany do rozwiązania zagadki.

${ }^{51}$ C. KuHL, Die drei Männer im Feuer, Giessen 1930, 72 (BZAW 55); W. BAuMgartner, Ein Vierteljahrhundert Danielforschung, 133; A. BENTZEN, Daniel 6: Ein Versuch zur Vorgeschichte der Märtyrerlegende, [w:] Festschrift A. Bertholet, hrsg. W. Baumgartner, O. Eissfeldt, K. Elliger, L. Rost, Tübingen 1950, 58-64.

${ }^{52}$ M. A. BEeK, Das Danielbuch. Sein historischer Hintergrund und seine literarische Entwicklung, Leiden 1935, 73. 
przeciwnie zostaje ocalony i cieszy się po prześladowaniu jeszcze większym uznaniem, nie może być traktowane jako opowiadanie o męczeństwie.

Głównym motywem opowiadań o dworskim współzawodnictwie w Dn 2, 4 i 5 oraz w paralelnym opowiadaniu o Józefie jest sukces, który odnosi dworzanin na królewskim dworze przy równoczesnym upokorzeniu lub upadku innych, najczęściej jego przeciwników. Fabuła tych opowiadań przebiega w następujących etapach:

1. Król nie może poradzić sobie z problemem, który go dręczy ${ }^{53}$.

2. Pozostali mędrcy (dworzanie) nie potrafią rozwiązać tego problemu ${ }^{54}$.

3. Główny bohater jest wezwany na dwór królewski, gdzie rozwiązuje problem dręczący króla. W ten sposób on odnosi sukces, podczas gdy pozostali ponoszą porażkę ${ }^{55}$.

4. Bohater jest obdarzony godnościami oraz wzrasta i umacnia się jego pozycja na dworze ${ }^{56}$.

Użycie określenia „opowiadania dworskie” na oznaczenie formy literackiej Dn 1-6 zostało skrytykowane przez niektórych uczonych ze względu na mała jego precyzyjnośćs7. Istnieje możliwość precyzyjnego określenia formy literackiej poszczególnych opowiadań, ale w stosunku do całej kompozycji Dn 1-6 możliwe jest jedynie wyszczególnienie ogólnych i powtarzających się motywów.

Niemniej warto zwrócić uwagę w badaniach nad formą literacką opowiadań w Dn 1-6 na analizę, która podkreśla obecność w nich motywów ludowych ${ }^{58}$. W analizie strukturalno-morfologicznej, którą stosują zwolennicy dostrzegania w opowiadaniach Dn 1-6 elementów folklorystycznych, nazywając je „opowiadaniami ludowymi”, podstawowym założeniem jest przyjęcie tezy o istnieniu ustnej tradycji poprzedzającej formę spisaną literatury

${ }^{53}$ Dn 2, 1: Nabuchodonozor ma sen; Dn 4, 2: Nabuchodonozor ma sen; Dn 5, 5-7: tajemniczy napis na ścianie; Rdz 41, 1-8: faraon ma sen; w Historii Achikara wykonanie niemożliwego zadania (zbudowanie pałacu między niebem a ziemią).

${ }^{54}$ Dn 2, 10-11; 4, 3-4; 5, 8; Rdz 41, 8.

${ }^{55}$ Dn 2, 25-45: Daniel zostaje wprowadzony na dwór królewski, opowiada sen królowi i go wyjaśnia; Dn 4, 17-24: Daniel wyjaśnia sen; Dn 5, 13-29: Daniel jest przyprowadzony przed króla i interpretuje napis na ścianie; Rdz 41, 25-36: Józef zostaje wezwany z więzienia i wyjaśnia sen faraonowi; Achikar jest wyprowadzony z ukrycia. W Dn 4 nie ma wprowadzenia na dwór, ponieważ Daniel już tam przebywa.

${ }^{56}$ Dn 2, 46-49: król wywyższa Daniela i czyni go zarządcą prowincji; Dn 5, 29: wywyższenie Daniela, król mianuje go rządcą, jednym z trzech zarządzających państwem; Rdz 41, 39-45: faraon mianuje Józefa rządcą Egiptu. W Dn 4 nie ma wywyższenia Daniela, ponieważ zajmuje on już tam wysokie stanowisko doradcy królewskiego.

${ }^{57}$ Zob. S. Niditch, R. Doran, The Success Story of the Wise Courtier: A Formal Approach, JBL 96 (1977), 179; K. Косн, Das Buch Daniel, 90; E. HAAG, Die Errettung Daniels, 83.

${ }^{58}$ Zob. omówienie historii badań i podstawowych założeń zwolenników metody, która włącza elementy folklorystyczne do analizy opowiadań w: L. M. WiLls, The Jew in the Court of the Foreign King, 3-10. 
biblijnej, co ma duży wpływ na określenie formy literackiej tekstu spisanego w jego dzisiejszej formie ${ }^{59}$. Kategorie, w których podkreśla się elementy folklorystyczne, między innymi samą treść narracji, liczne powtórzenia, fabułę, typologię charakterów, wspólne motywy występujące w różnych kulturach, są niewątpliwie pomocne w określeniu formy literackiej w Dn 1-6. Należy jednak stwierdzić, że przy podkreślaniu uniwersalnych aspektów wspólnych dla różnych kultur, równocześnie mniejszą wagę przywiązuje się do lokalnego kolorytu poszczególnych opowiadań, który przede wszystkim jest zdominowany przez ich Sitz im Leben na dworze królewskim.

Analiza przeprowadzona przez S. Niditch i R. Doran ${ }^{60}$ jest przykładem zastosowania wyników badań folklorystycznych do opowiadań, zwłaszcza Dn 2, Rdz 37-50 i Historii Achikara 5-7. Zastosowali oni indeks typów opowiadań opracowany przez A. Aarne i S. Thompsona, którzy zebrali i skatalogowali tysiące opowiadań ludowych według poszczególnych motywów i ich aranżacji. Każda aranżacja różnych motywów została nazwana „typem” i opatrzona numerem katalogowym. Według tej klasyfikacji powyższe opowiadania uzyskały numer i typ 922 oraz zostały zatytułowane „Mądre czyny i słowa”. Podstawowym motywem tych opowiadań jest awans osoby o niskim statusie społecznym na wysokie stanowisko państwowe. Punktem centralnym tych dworskich opowiadań staje się wywyższenie mądrego i sprawiedliwego bohatera oraz uznanie jego autorytetu przez pozostałych.

Nawiązując do analizy przeprowadzonej przez S. Niditch i R. Doran, propozycję nowej formy literackiej w odniesieniu do opowiadań Dn 1-6, Rdz 37-50, Księgi Hioba, Tobiasza, Estery i Historii Achikara wysunął H. P. Müller ${ }^{61}$. Opierając się na spostrzeżeniach G. von Rada ${ }^{62}$, sugeruje on, aby te opowiadania nazwać „mądrościowymi opowiadaniami dydaktycznymi”. H. P. Müller nie przywiązuje większej wagi do Sitz im Leben tych opowiadań na królewskim dworze, ile raczej zwraca uwagę na niektóre aspekty charakterystyczne dla formy literackiej, którą można nazwać dydaktyczną, między innymi na rolę pośrednika, którą spełnia król w konflikcie między dworzanami. Ten konflikt może być traktowany jako konfrontacja dobra (dworzanin pozytywny) oraz zła (dworzanin negatywny).

Przeprowadzając analizę metodą morfologiczno-synchroniczną proponuje on następującą strukturę:

${ }^{59}$ S. Niditch, Folklore and the Hebrew Bible, Minneapolis 1993, 6-9 (Guides to Biblical Scholarship. Old Testament Series).

${ }^{60}$ Zob. S. Niditch, R. Doran, The Success Story of the Wise Courtier, 179-193; zob. również P. J. Milne, Folktales and Fairy Tales: An Evaluation of Two Proppian Analyses of Biblical Narratives, JSOT 34 (1986), 35-60.

${ }^{61}$ Zob. H. P. Müller, Die weisheitliche Lehrerzählung in Alten Testament und seiner Umwelt, WO 9 (1977), 77-98. 


\section{WSTĘP:}

1. Protagonista zostaje opisany jako człowiek prawy i sprawiedliwy.

2. Symboliczne czyny, które wypływają z jego prawości, oraz podkreślenie jego szlachetności.

3. Zostaje wprowadzony antagonista oraz jego zwolennicy.

ROZWINIĘCIE:

1. Powstaje konflikt z powodu prawości i szlachetności protagonisty.

2. Szlachetność i prawość protagonisty zostaje poddana próbie.

\section{ZAKOŃCZENIE:}

1. Umocnienie prawości protagonisty przez ukaranie antagonistów.

2. Umocnienie prawości przez nagrodzenie protagonisty.

3. Umocnienie prawości potwierdzone cudownym wydarzeniem.

$\mathrm{Z}$ podkreśleniem elementu mądrościowego i dydaktycznego zgadza się L. M. Wills. Proponuje, aby opowiadania, zwłaszcza Dn 1-6 i Księgę Estery, nazywać „mądrościowymi legendami dworskimi”“33. Określenie „legenda”, które sugeruje L. M. Wills różni się zwróceniem uwagi na intencję i właściwości narracji, a nie na Sitz im Leben oraz różną strukturę, co czyni określenie „opowiadanie dworskie”. Samo określenie „legenda” jest tematem wielu dyskusji ${ }^{4}$. Wydaje się, że można wszystkie propozycje ująć w stwierdzeniu, iż legenda jest opowiadaniem narracyjnym pierwotnie skoncentrowanym wokół tematu cudowności, którego głównym celem jest pouczenie $^{65}$. Opowiadania w Dn 1-6 zawierają liczne elementy cudowności, niezwykłych i nadprzyrodzonych wydarzeń, których brak na przykład w Historii Achikara i w Księdze Estery. W obecnej formie Księgi Daniela te elementy cudowności są jeszcze bardziej podkreślone przez liczne doksologie, ale sam temat cudowności i niezwykłości był już obecny w pierwotnej wersji opowiadań. Właśnie ten aspekt opowiadań w Dn 1-6 jest w sposób bardziej precyzyjny wyrażony, gdy opowiadania określa się terminem „legend dworskich” aniżeli „opowiadań dworskich”.

Niezależnie od tego, w jaki sposób nazwie się część narracyjną Dn 16, można w poszczególnych opowiadaniach wyodrębnić liczne podrzędne formy literackie. J. G. Gammie wyróżnia następujące ${ }^{66}$ :

- opis snu (sennej wizji), Dn 2, 31-36; 4, 1-15. Relacja o śnie jest określona jako ḥelmā’ i wprowadzona przez formułę: hāzē̄h hăwáytāa wa’ălû. Relacje o śnie, zwłaszcza w opowiadaniach o Józefie i Danielu, określa się terminem

\footnotetext{
${ }^{62}$ Zob. G. von RAD, Weisheit in Israel, Neukirchen 1970, 67.

${ }^{63}$ Zob. L. M. Wills, The Jew in the Court of the Foreign King, 12.

${ }^{64}$ Zob. tamże, 12-19.

${ }^{65}$ Zob. J. J. Collins, Daniel, 44.

${ }^{66}$ Zob. J. G. Gammie, The Classification, 193-194.
} 
snów symbolicznych ${ }^{67}$, w obu przypadkach sny wymagają interpretacji, a ich Sitz im Leben jest dwór królewski obcego władcy.

- interpretacja $s n u^{68}$, Dn 2, 36-45; 4, 16-24. Na oznaczenie interpretacji snu użyty zostaje termin pəšar lub jego forma emfatyczna pišrā’ (hebr. pešer, pitrôn) w Dn 2 i 4 oraz na określenie interpretacji tajemniczego napisu na ścianie w Dn 5. Ten sam termin występuje w opowiadaniach o Józefie. Peszer w Księdze Daniela nie jest używany w tym samym sensie jak w Qumran, gdzie posiada określoną strukturę i polega na wyjaśnianiu kolejnych, następujących po sobie jednostek tekstu, a jest wprowadzany przez ustalone formuły ${ }^{69}$. Genezą peszeru jako formy literackiej jest interpretacja snu w ścisłym tego słowa znaczeniu. W języku akkadyjskim czasownik pašāru, określający formę literacką ,interpretacji snu” zawierał: (a) opis snu lub opowiedzenie treści snu innej osobie, (b) interpretację snu, najczęściej za pośrednictwem bóstwa, (c) zwycięstwo nad złem, które zagrażało za pośrednictwem snu ${ }^{70}$. Określenie ,peszer” jest ściśle związane z terminem „midrasz egzegetyczny”, dlatego niekiedy uważa się, że aktualizowanie starszych materiałów w czasach Antiocha Epifanesa przez ostatniego redaktora nadało całej Księdze Daniela formę peszeru czy midraszu egzegetycznego na temat wcześniejszych wypowiedzi biblijnych ${ }^{71}$. Jest to jednak zbytnie uogólnienie w stosunku do treści całej Księgi.

- vaticinia ex eventu ${ }^{72}$, Dn 2, 32-33. 37-43. Ta forma literacka, polegająca na przedstawieniu proroctwa o zdarzeniach, które już miały miejsce, jest spotykana we wszystkich żydowskich apokalipsach historycznych, a przede wszystkim w Apokalipsie Tygodni, 4 Księdze Ezdrasza i 2 Księdze Barucha. Jest również poświadczona w literaturze biblijnej, a jednym z najwcześniejszych przykładów proroctwa ex eventu jest Rdz 15, 13-16. W apokaliptyce vaticinia ex eventu zawsze kończą się konkluzją eschatologiczną.

- proroctwa eschatologiczne, Dn 2, 34-35. 44-45.

- dekrety królewskie, Dn 3, 29; 4, 36; 6, 27-2873. Jak zauważył J. A. Fitzmy$\mathrm{er}^{74}$, królewskie dekrety mają najczęściej formę listu. Z tą formą literacką

${ }^{67}$ Zob. J. J. Collins, Daniel with an Introduction, 13.

${ }^{68}$ Zob. A. FinkeL, The Pesher of Dreams and Scriptures, RQ 4 (1963-1964), 357-370; zob. też I. Rabinowitz, „Pēsher/pittārōn”. Its Biblical Meaning and its Significance in the Qumran Literature, RQ 8 (1972-1973), 219-232.

${ }^{69}$ Zob. M. P. Horgan, Pesharim: Qumran Interpretations of Biblical Books, Washington 1979, 229-259 (CBQMS 8).

${ }^{70}$ Zob. A. L. OpPenheim, The Interpretation of Dreams in the Ancient Near East. With a Translation of an Assyrian Dream-Book, Philadelphia 1956, 217-225 (Transactions of the American Philosophical Society, 3).

${ }^{71}$ Zob. A. SZÖRÉNYI, Das Buch Daniel, ein kanonisierter Pescher?, VTSup 15 (1966), 278-294.

72 Zob. szerzej na ten temat E. Osswald, Zum Problem der vaticinia ex eventu, ZAW 75 (1963), 27-44. 
można się spotkać zarówno w literaturze biblijnej (Ezd 4-7; Est 3), jak również pozabiblijnej (Józef Flawiusz, Ant. 12, 3, 3-4).

- wykazy (spisy, listy). Ta forma literacka obejmuje wykazy, które są charakterystyczne dla stylu narracyjnego Dn 1-6. Różnią się od siebie wzajemnie treścią, mamy bowiem m.in. wykaz urzędników świeckich (Dn 3, 2.3; 6, 8), wykaz urzędników kultycznych (Dn 2, 2.10.27; 4, 4; 5, 7.11), wykaz instrumentów muzycznych (Dn 3, 5.7.10.15), wykaz metali (Dn 2, 35. 45; 5, 4), wykaz ubrań (Dn 3, 21), wykaz osób z otoczenia króla (Dn 5, 2), wykaz narodowości (Dn 3, 4. 29). Jak zauważa P. W. Coxon ${ }^{75}$, forma literacka nazwana „wykazem, listą” wykazuje pochodzenie ze starych tradycji mądrościowych Egiptu i Babilonii, a liczne powtórzenia są przemyślaną formą zawierającą elementy retoryczne i ironiczne w celu lepszego wyrażenia przekazywanych treści.

- doksologie ${ }^{76}$, Dn 2, 20-23; 3, 31-33; 4, 31-32[34]; 6, 26-28. Wszystkie doksologie mają poetycką formę uwielbienia sięgającą korzeniami do starych tradycji Izraela wyrażonych przede wszystkim w psalmach. Element uwielbienia jest niekiedy uzupełniony przez dziękczynienie. Doksologie w Dn 1-6 czasem dosłownie odwołują się do starszych tradycji ST (Ps 145, 13), a niekiedy przez uwypuklenie prawdy o panowaniu Boga nawiązują do hymnów sławiących Jego potęgę jako Stwórcy i posiadającego najwyższą wiedzę Króla (Ps 29, 10; 104, 31).

- aretalogie, Dn 3, 5 i 6 . Ta forma literacka jest określana jako opowiadanie zawierające element cudowności. Zwłaszcza w opowiadaniach Dn 3 i 6 spotyka się podobną fabułę: główny bohater jest w niebezpieczeństwie, z którego zostaje ocalony przez cudowną interwencję.

\section{Wizje: Dn 7-12}

Określenie formy literackiej w Dn 7-12 sprawia uczonym wiele trudności i dlatego, podobnie jak w przypadku Księgi Daniela jako całości, dąży się raczej do ich opisania niż do zdefiniowania. Twierdzi się, że sekcja wizji w Księdze Daniela pod względem literackim jest sui generis, co jednak wcale nie znaczy, że nie można poddać pewnej klasyfikacji występujących w Dn 712 apokaliptycznych wizji. Trzeba jednak mieć na uwadze fakt, iż nie należy traktować wizji jako reprezentujących określony gatunek literacki, ile raczej odbierać je jako zespół form literackich ujmowanych jako wizja ${ }^{77}$.

${ }^{73}$ Zob. J. H. WALton, The Decree of Darius the Mede in Daniel 6, JETS 31 (1988), 279-286.

${ }^{74}$ Zob. J. A. Fitzmyer, Some Notes on Aramaic Epistolography, JBL 93 (1974), 205.

${ }^{75}$ Zob. P. W. Coxon, The 'List' Genre and Narrative Style in the Court Tales of Daniel, JSOT 35 (1986), 95-121.

${ }^{76}$ Szerzej na ten temat zob. W. S. Towner, The Poetic Passages of Daniel 1-6, CBQ 31 (1969), 317-326. 
Ogólnym terminem na określenie objawienia w widzialnej formie jest „wizja”. Jej przyjęcie i zrozumienie różni się od zwyczajnej percepcji rzeczywistości, a jej dostępność jest zarezerwowana tylko dla wybranych. Określając formę literacką apokaliptycznych wizji w Dn 7-12 można stwierdzić, że posiadają one następujące cechy:

- chociaż apokalipsy najczęściej zawierają objawienie odnoszące się do przeszłości, rzeczywistości niebiańskiej lub odległej przyszłości, to Dn 7-12 koncentruje się wokół teraźniejszości mieszczącej się pomiędzy początkiem i końcem historii ujętej w schemat czterech epok - królestw (piąta epoka to królestwo ustanowione przez Boga);

- wizje poprzez periodyzację historii w schemacie czterech królestw uczą, że historia zmierza do końca czasu, który jest już blisko i jest nieunikniony, lecz nie znana jest natura tego końca;

- pomimo tego, że wizje są osadzone w realiach historycznych, ich historyczność jest fikcyjna;

- aby objawieniom nadać autorytet, zostały one przypisane mędrcowi;

- aby wyjaśnić nagłe pojawienie się wizji, są one ukazane jako niedostępne (zapieczętowane), aż do określonego czasu;

- objawienie Bożych tajemnic następuje w dwóch formach: jako wizja oraz jej interpretacja. Wizja jest objawiona tylko wybranej osobie, która ją otrzymuje, natomiast interpretacja jest dana tej osobie najczęściej przez istotę pozaziemską, która pełni rolę interpretatora.

Zaliczając Księgę Daniela do grupy apokalips historycznych, J. J. Collins wyróżnia w niej środki przekazu objawienia oraz treść objawienia, które określa jako poszczególne gatunki czy formy literackie ${ }^{78}$. Wizje w Dn 7-12, podobnie jak większość apokalips w ścisłym tego słowa znaczeniu, odznaczają się pseudonimią, ekstatycznym doświadczeniem i ezoteryzmem ${ }^{79}$.

Najbardziej reprezentatywną i wspólną formą literacką zawierającą objawienie jest „wizja symboliczna” lub „symboliczna wizja senna”, między innymi w Dn 7-8; 1 Hen 83-84; 85-91; 4 Ezd 11-13; 2 Bar 35-47; 53-77.

Symboliczna wizja senna w Dn 7 i 8 zawiera następujące elementy:

1. Wskazanie okoliczności: chronologicznych i dotyczących miejsca lub sposobu objawienia.

${ }^{77}$ Taką sugestię wysunął N. W. Porteous, a za nim podjął ją P. R. DAVIEs, Daniel, 68.

${ }^{78}$ Zob. Daniel with an Introduction, 12-19.

${ }^{79}$ M. E. Stone, Apocalyptic Literature, [w:] Jewish Writings of the Second Temple Period. Apocrypha, Pseudepigrapha, Qumran Sectarian Writings, Philo, Josephus, ed. M. E. Stone, Assen-Philadelphia 1984, 427-433 (CRINT 2.2); zob. także M. E. STONE, Apocalyptic - Vision or Hallucination?, Milla wa-Milla 14 (1974), 47-56. 
2. Opis wizji wprowadzony przez formułę: waวărû w Dn 7, 2; wəhinnēh w Dn 8, 3.

3. Prośba o interpretację.

4. Interpretacja, którą widzący otrzymuje od istoty niebiańskiej.

5. Zakończenie może zawierać reakcję widzącego, instrukcje istoty niebiańskiej lub pouczenie.

Symboliczne wizje w apokaliptyce (Księga Daniela, 4 Księga Ezdrasza, 2 Księga Barucha) są rezultatem długiego procesu ich rozwoju począwszy od prorockich wizji Amosa, Jeremiasza i Zachariasza. Mimo, że wizje w apokalipsach stają się pewnego rodzaju kontynuacją tradycji prorockich, wykazują one jednak dalszy ich rozwój ${ }^{80}$. Zwłaszcza symbolizm Księgi Daniela jest bogatszy i zawiera o wiele więcej aluzji. Do pierwszego stadium rozwoju ${ }^{81}$ można zaliczyć symboliczne wizje w Am 7, 7-9 i 8, 1-3 oraz w Jr 1, 11-12; 1, 13-19 i 24. Można je uważać za prekursorów tej formy literackiej: są bardzo proste i nie posiadają jeszcze jednolitego układu treści, który w późniejszych fazach rozwoju przybiera postać utartych stereotypów. Do drugiego stadium ${ }^{82}$ zalicza się wizje w Zach 1, 7-17; 2, 1-4; 2, 5-9; 4, 1-6a. 10b-14; 5, 1-4; 5, 5-11; 6, 1-8. Wizje w Księdze Zachariasza odznaczają się już przejrzystą budową: wskazanie na okoliczności, opis wizji i obecność anioła jako interpretatora, co zbliża je do formy apokaliptycznej symbolicznej wizji.

Uznanie wizji jako kontynuacji tradycji prorockich nie jest sprawą do końca oczywistą. Dn 2, zawierający liczne paralele do wizji z Dn 7, swój odpowiednik znajduje nie w wizjach prorockich, a w opowiadaniach o Józefie, które są zakorzenione w tradycji mądrościowej. To spostrzeżenie prowadzi do wniosku, że w Dn 7-12 literacka forma jest zaczerpnięta z różnych źródeł i w efekcie „,wizje” w obecnej postaci Księgi Daniela są połączeniem form profetycznych i mądrościowych, obecnych zarówno w literaturze biblijnej, jak i w pozabiblijnej ${ }^{83}$.

Należy również zauważyć, że symboliczne wizje obecne w tradycji prorockiej a rozwinięte w apokaliptyce są adaptacją o wiele starszej formy symbolicznego snu, którego istnienie jest poświadczone w literaturze całego Bliskiego Wscho$\mathrm{du}^{84}$. Przykładem mogą być sny w eposie Gilgamesz ${ }^{85}$, symboliczny sen sumeryjskiego władcy Gudei czy sen faraona Tantamani ${ }^{86}$. Jak zauważył J. J. Collins, intrygującą paralelą jest symboliczna wizja Zaratustry w perskim poemacie

${ }^{80}$ Szerzej na temat rozwoju symbolicznej wizji jako formy boskiego objawienia w tradycji biblijnej zob. S. Niditch, The Symbolic Vision in Biblical Tradition, Chico 1983 (HSM 30); K. KocH, Vom profetischen zum apokalyptischen Visionsbericht, [w:] Apocalypticism, ed. D. Hellholm, 387-411.

${ }^{81}$ Zob. S. Niditch, The Symbolic Vision, 21-72.

${ }^{82}$ Zob. tamże, s. 73-175.

${ }^{83}$ Zob. P. R. DAvies, Daniel, 69-70. Na temat tradycji mądrościowych w apokaliptyce zob. G. von RAD, Teologia Starego Testamentu, tł. B. Widła, Warszawa 1986, 597-602. 
Zand-i Vohuman Yasht ${ }^{87}$. Otóż Zaratustra w wizji widzi drzewo z czterema owocami (w innym wariancie tego poematu drzewo ma siedem owoców). Ahura Mazda interpretuje cztery owoce jako epoki, które mają nadejść.

W historii formy literackiej, jaka jest symboliczna wizja wiele spraw pozostaje niejasnych. Z pewnością ta forma jest kontynuacją tradycji biblijnej, zarówno prorockiej, jak i mądrościowej, ale trzeba brać również pod uwage wpływ form znanych w literaturze pozabiblijnej, zwłaszcza mezopotamskiej i perskiej, takich jak opis snu, senna wizja czy jego interpretacja.

Kolejnym środkiem przekazu objawienia jest forma literacka określana jako „epifania apokaliptyczna”88. Charakteryzuje się tym, iż pojawia się w niej wizja istoty pozaziemskiej, jak na przykład w Dn 10 . Z pewnością tego typu forma literacka odznacza się mniejszym zakresem niż symboliczna wizja, ale przejmuje z tej formy literackiej pewne elementy. W konstrukcji Dn 10 można wyróżnić wskazanie okoliczności wizji oraz reakcję widzącego. Zamiast interpretacji pojawia się mowa istoty pozaziemskiej, która zawiera treść objawienia. Epifania może również być częścią innej formy literackiej bądź też wchodzić w skład wizji w szerszym znaczeniu, jak na przykład pojawienie się postaci jakby Syna Człowieczego w Dn 7, 13.

Prekursorem apokaliptycznej epifanii jest Księga Ezechiela, między innymi wizja rydwanu Bożego w Ez 1-2 i wizja anioła w Ez 8. W szerszym znaczeniu epifania jako środek objawienia jest modyfikacją wspólnej formy określanej jako „senne przesłanie” ${ }^{89}$. W literaturze biblijnej często występują opisy przybycia Boga do człowieka we śnie z określonym przesłaniem, które rozpoczyna się zwykle formułą wprowadzającą: wayyābo ō ’ ’̌lōhîm [...] bahạălôm hallấylāh ${ }^{\mathrm{h}}(\mathrm{Rdz}$ 20,3;31, 24; $1 \mathrm{Krl} 3,5 ; 9,2)$, lecz bez opisu samego objawienia się. W literaturze pozabiblijnej boska epifania jest ujęta w formę opisu snu z przesłaniem. W śnie Gudei objawia się mu Ningirsu, faraon Merneptah we śnie widzi Ptaha.

${ }^{84}$ Typowy opis snu zawierający schematyczną budowę występuje w literaturze starożytnego Sumeru, Egiptu, Babilonii i Grecji. Forma opisu snu zawiera wprowadzenie mówiące o śniącym, wskazanie okoliczności, relację o samym śnie i zakończenie, w którym mowa jest o reakcji śniącego, a często o wypełnieniu snu, pouczeniu lub obietnicy; zob. szerzej A. L. OpPenheIm, The Interpretation of Dreams, 187.

${ }^{85}$ Zob. R. STiller, Gilgamesz. Epos starożytnego dwurzecza, Warszawa 1980: sen Gilgamesza o spotkaniu przyjaciela Enkidu (s. 43-44); sen Gilgamesza o zwycięstwie nad Humbabą (s. 67-68); sen Enkidu o swojej śmierci (s. 76-78).

${ }^{86}$ Zob. szerzej A. L. OpPEnHEIM, The Interpretation of Dreams, 245-246.

${ }^{87}$ Zob. J. J. Collins, Daniel with an Introduction, 14.

${ }^{88}$ Zob. tamże, 14-15.

${ }^{89}$ A. L. OppenHeIM, The Interpretation of Dreams, 191, zauważa, że na Bliskim Wschodzie epifania stała się prototypem formy literackiej określanej mianem sennego przesłania. Bóstwo ukazywało się najczęściej w czasie snu i kierowało swoje przesłanie do śpiącego człowieka. 
Połączeniem epifanii i symbolicznego snu jest 4 Ezd 9, 26-10, 59, gdzie Ezdrasz widzi kobietę i rozpoczyna z nią dialog. Potem pojawia się anioł Uriel i wyjaśnia, że ta kobieta to Syjon.

Następną formą literacką w ramach przekazu objawienia jest „przemówienie anioła" ${ }^{\circ 0}$, które polega na objawieniu treści objawienia przez mowę anioła skierowaną do widzącego. Forma literacka mająca postać „przemówienia anioła" może być następstwem epifanii, tak jak to jest w przypadku Dn 10-11, lub też może być pozbawiona elementów wizualnych, jak na przykład w Jub 2. Ta forma literacka dominuje w Dn 9, gdzie staje się peszerem lub midraszem egzegetycznym do Jr 25, 11-12 i 29, 10. Forma literacka, która jest nazywana przemówieniem anioła, ma również swoje podłoże w „sennym przesłaniu”, formie przekazu objawienia, jaka często występuje w literaturze Bliskiego Wschodu.

Przemówienie anioła w Dn 8, 23-25 i Dn 11 zawiera formę literacką określaną jako „proroctwo o panowaniu” lub „dynastyczne”, którego podłożem może być proroctwo dynastyczne bardzo często występujące w Babilonii ${ }^{11}$. Cechą charakterystyczną tej formy jest użycie anonimowej formuły o „powstającym królu”: wə‘āmad [...] melek (np. Dn 11, 3. 7). Ukazanie Antiocha Epifanesa jako stawiającego się nawet ponad Boga jest adaptacją kananejskiego mitu o buncie w niebie, którego echem są teksty w Iz 14, 3-21 i Ez 28, 1-1992.

Formą literacką, która zwykle pojawia się jako część symbolicznej wizji, jest „dialog objawieniowy”"93. Najczęściej jest to konwersacja pomiędzy osobą objawiającą się (Bóg lub anioł) a osobą otrzymującą objawienie w postaci wizji. W Dn 10-12 objawieniowy dialog zawiera również cechy przemówienia anioła i jest połączony z epifanią, która zawiera wskazanie okoliczności i predyspozycji widzącego. W Księdze Daniela trudno jednoznacznie rozróżnić objawieniowy dialog od przemówienia anioła, w pełni ta forma przekazu objawienia rozwinie się w późniejszych apokalipsach, takich jak 4 Księga Ezdrasza i 2 Księga Barucha.

Treść „apokalips historycznych” posiada swoje własne typowe formy przekazu. Jak zauważa J. G. Gammie ${ }^{94}$, do form literackich apokaliptycznych wizji należą, podobnie jak w przypadku opowiadań w Dn 1-6, vaticinia ex eventu (Dn 7, 1-8. 15-17. 19-21. 23-25; 8, 1-27; 10, 13; 11, 1-39), proroctwa eschatologiczne (Dn 7, 12-14. 18. 22. 26-27; 11, 40-45; 12, 1-11) oraz „napomnienia”

${ }^{90}$ Zob. J. J. Collins, Daniel with an Introduction, 15.

${ }^{91}$ Zob. A. Grayson, Babylonian Historical-Literary Texts, Toronto 1975, 21 (Toronto Semitic Texts and Studies, 3).

${ }^{92}$ Zob. R. J. Clifford, History and Myth in Daniel 10-12, BASOR 220 (1975), 25.

${ }^{93}$ Zob. tamże, s. 15.

${ }^{94}$ Zob. J. G. Gammie, The Classification, 194. 
(Dn 12, 13a). Charakterystyczną cechą apokalipsy jest również „periodyzacja historii”, a więc podzielenie jej na poszczególne etapy, jak na przykład w Dn 7 na cztery królestwa, czy w Dn 9 na siedemdziesiąt tygodni.

Formą literacką, która jest traktowana jako podrzędna forma Dn 7, jest „scena sądu” w ww. 9-1495. Forma literacka zawierająca opis sądu występuje we wszystkich apokalipsach, ponadto jak na przykład w 1 Hen 27 jest zawarty opis miejsca sądu, a w 1 Hen 53 przygotowanie do niego. Jak dowodzi G. W. E. Nickelsburg ${ }^{96}$, opis zmartwychwstania w Dn 12, 1-3 oraz paralelne opisy w TestMż 10, Jub 23, 27-31 i TestJud 25, wykazuje również cechy „sceny sądowej”.

Wyróżnia w niej następujące konstytutywne elementy:

- świadkowie: wystąpienie Michała jako wojownika stojącego na czele niebiańskiej armii Izraela suponuje istnienie opozycji;

- księga życia, jako wykaz ludzkich czynów odpowiadających świadectwu aniołów;

- zmartwychwstanie, dzięki któremu zmarli mogą uczestniczyć w sądzie;

- konsekwencje sądu: nagroda dla sprawiedliwych oraz potępienie występnych.

Należy jednak zauważyć, że w Dn 12, 1-3 brakuje podstawowego elementu „sceny sądowej”, a mianowicie przewodniczącego sądu, czyli Boga. Nie jest również jasne, czy Michał pełni tutaj rolę świadka, jak sugeruje to G. W. E. Nickelsburg powołując się na Zach 3, gdzie jest mowa o aniołach jako obrońcach. Jedynie aluzja do księgi życia suponuje obecność sceny sądu, chociaż brak opisu jej samej. Należy więc uznać, że Dn 12, 1-3 jest eschatologicznym proroctwem, jak sugerował to J. G. Gammie.

Częścią formy literackiej określanej jako „scena sądu” jest „wizja tronu” w Dn 7, 9-10. Jest to wizja Boga zasiadającego na tronie. Ta forma literacka wywodzi się z tradycji biblijnej, która opiera się na teofanii $(1 \mathrm{Krl} 22$, 19; Iz 6, 1-4; Ez 1) ${ }^{97}$. W Dn 7 ,wizja tronu” jest częścią większej sceny sądu z intronizacją niebiańskiego sędziego, otwarciem ksiąg i wyrokiem sądu. W szerszym kontekście forma ta zawiera również epifanię postaci jakby Syna Człowieczego.

Wizja tronu posiada charakterystyczne dla tej formy literackiej motywy: Bóg zasiadający na tronie, Jego otoczenie stanowią zastępy aniołów, nie-

${ }^{95}$ Zob. J. E. Goldingay, Daniel, Dallas 1989, 147 (WBC 30).

${ }^{96}$ Zob. G. W. E. Nickelsburg, Resurrection, Immortality, and Eternal Life in Intertestamental Judaism, Cambridge-London 1972, 39-42 (HTS 26).

${ }^{97}$ Zob. szerzej M. BLack, The Throne-Theophany Prophetic Commission and the 'Son of Man', [w:] Jews, Greeks, and Christian, Festschrift W. D. Davies, eds. R. G. Hamerton-Kelly, R. Scroggs, Leiden 1976, 57-73 (SJLA 21); T. HIEBERT, Theophany in the OT, [w:] ABD 6, 505-511. 
odłącznym elementem są zjawiska przyrody, takie jak ogień, wiatr, burza czy błyskawice, oraz uwielbienie odbierane od aniołów ${ }^{98}$.

W Dn 9 występuje forma literacka określana jako „wspólne wyznanie grzechów”, która przybiera postać modlitwy. Podobne formy modlitwy, w których następuje wyznanie grzechów i prośba o miłosierdzie, występują między innymi w Ps 106; Ezd 9, 6-15; Neh 1, 5-11; 9, 5-37; Bar 1, 15 - 3, 8. Wszystkie te modlitwy odwołują się do tak zwanej formy Przymierza i mają typową budowę:

- wyznanie o złamaniu Przymierza,

- uznanie Bożej sprawiedliwości,

- wspomnienie Bożego miłosierdzia,

- błagalne zwrócenie się do Boga o miłosierdzie.

Podobne elementy występują też w Modlitwie Azariasza w deuterokanonicznej części Księgi Daniela (3, 25-45).

Podsumowując można stwierdzić, że Księga Daniela jako całość stanowiąca apokalipsę może być zaliczona do grupy tzw. apokalips historycznych, co bardziej oddaje jej złożony charakter, zwłaszcza istnienie w niej części narracyjnej (Dn 1-6) oraz wizji (Dn 7-12).

Mając na uwadze zarówno formę literacką, jak i Sitz im Leben opowiadań zawartych w Dn 1-6, należy uznać je za „opowiadania dworskie” lub „legendy dworskie”, co jeszcze bardziej podkreśla ich charakter dydaktyczny. W odniesieniu do formy literackiej Dn 7-12 samo określenie „wizja” jest mało precyzyjne. Charakter wizji zawartych w Dn 7 i 8 dobrze oddaje określenie „symboliczne wizje senne”. Bardzo istotne jest wyodrębnienie poszczególnych jednostek literackich i precyzyjne ich określenie. W przypadku opowiadań z Dn 1-6 są to: opis snu, interpretacja snu, vaticinia ex eventu, proroctwo eschatologiczne, dekret królewski, wykazy (spisy, listy), doksologie i aretalogie. W przypadku wizji z Dn 7-12 sa to: wizja symboliczna, epifania apokaliptyczna, przemówienie anioła, proroctwo o panowaniu (dynastyczne), dialog objawieniowy, napomnienie, periodyzacja historii, scena sądu, wizja tronu. Odrębną formę literacką stanowi Dn 9, a mianowicie tzw. wspólne wyznanie grzechów. Chociaż niektóre z form literackich są wspólne dla opowiadań i wizji, większość z nich jest jednak charakterystyczna wyłącznie czy to dla opowiadań, czy to dla wizji i stanowi ich konstytutywne elementy.

Rzym

KS. MAREK PARCHEM

${ }^{98}$ Zob. szerzej C. RowLAND, Visions of God in Apocalyptic Literature, JSJ 10 (1979), 138-154. 


\section{Riassunto}

\section{Il genere e le forme letterarie nel Libro di Daniele}

Nell'articolo l'autore si occupa del genere letterario di Dn e delle singole parti di questo libro biblico. Presenta un vasto panorama delle opinioni a proposito e si esprime a favore di quelle che gli sembrano più adeguate. Allora, come insieme, Dn va annoverato a causa del suo carattere composto fra le cosiddette apocalissi storiche. In Dn 1-6 bisogna vedere i racconti o leggende di corte, con forte indirizzo didattico. Questi racconti sono composti di piccole forme letterarie come: descrizione ed interpretazione del sogno, vaticinium ex even$t u$, profezia escatologica, decreto del re, elenco, dossologia e aretalogia. In Dn 7-12 invece riscontriamo le visioni, nei capitoli 7 e 8 le simboliche visioni sognatori. Le forme presenti qui sono: visione simbolica, epifania apocalittica, discorso dell'angelo, profezia dinastica, dialogo rivelatore, ammonimento, storia periodizzata, scena del giudizio, visione del trono. Infine Dn 9 è una comune confessione dei peccati.

\section{Summary}

\section{The biblical account of the Flood and the Mesopotamian documents}

It is nowadays clear that Hebrew tradition must have received its material for biblical account of the Flood from some Mesopotamian sources. The XI Tablet of the Gilgamesh Epic is acknowledged by most scholars to be the prototype of biblical account, but also other opinions were presented. The paper deals with interrelationship between the biblical account and Mesopotamian document (tablet) from Nippur The Flood Story. There is shown detailed correspondence - as well as difference - of the two to proof the hypothesis that the author of Yahwistic (J) version in Genesis has adjusted the data of the document to his own needs and concepts. 